\title{
GENDER-SPECIFIC ADJECTIVES IN CZECH NEWSPAPERS AND MAGAZINES
}

\author{
ADRIAN JAN ZASINA \\ Institute of the Czech National Corpus, Charles University, Prague, Czech Republic
}

ZASINA, Adrian Jan: Gender-specific adjectives in Czech newspapers and magazines. Journal of Linguistics, 2019, Vol. 70, No 2, pp. 299 - 312.

\begin{abstract}
This study is one of the few studies dealing with gender in the Czech language using corpus methods. It focuses on the issue of gender in Czech journalistic texts from the years 2010-2014. The main goal was to investigate the extent of stereotypical images of men and women in the press. This analysis is based on adjectival collocations of the lexemes muž 'man' and žena 'woman' and their semantic categorization. The research uses a journalistic part of the SYN2015 corpus. First, gender-specific adjectival collocates were identified. Second, adjectival collocates were classified into semantic categories and analyzed within journalistic genres. This study has shown that certain adjectives tend to co-occur with one of the examined lexemes and project a gender-stereotypical image of men and women within particular journalistic genres. It was confirmed that men are strongly associated with age specification, strength, appearance, and negative situations as a subject of crime, whereas women are related to motherhood, attractiveness, ethnicity, nationality, and are more often seen as victims of crime.
\end{abstract}

Keywords: gender studies, language and gender, discourse analysis, corpus linguistics, sociolinguistics

\section{INTRODUCTION}

Using corpus methods to analyze gender in language does not have a long tradition in the Czech environment. Previous studies carried out in this area are of a rather qualitative nature ([8], [10], [23]). Nevertheless, studies using quantitative methods ([21], [9], [26]) have also appeared in recent years. Inasmuch as the corpus analysis of gender in the Czech language has no long-term tradition, the present paper was inspired by a great deal of corpus-based research on gender in English-language discourse ([18], [5], [1], [15], [22], [17], [2]). Moreover, this study is based on earlier pilot analyses of collocation profiles of the nouns man and woman in Czech ([24], [25]).

The paper focuses on the issue of gender in Czech journalistic texts from the years 2010-2014. In particular, it aims to systematically describe a profile of premodifying adjectives co-occurring exclusively or predominantly with the nouns mиц̌, 'man,' or žena, 'woman'. It also emphasizes the occurrence of the analysed 
adjectival collocations within the journalistic genres, revealing gender stereotypical tendencies.

Gender "stereotypes" typically refer to the identification of the desirable identities of "hegemonic masculinity" and "preferred femininity" [23, pp. 8-10]. According to psychological studies [11, p. 121], men are described as aggressive, tough, and assertive, whereas women are viewed as kind, gentle, warm, and passive. This stereotypical view of men and women has also been noted in the Czech language [10]. However, a complex empirical study considering the collocational patterns of adjectives that co-occur with the lexemes muž and žena is still missing. Therefore, the objective of the present paper is to fill this gap and propose a comprehensive framework to study gender in the Czech language.

First, I describe the data applied in my research and the research questions. Second, I focus on the analysis of premodifying adjectives collocating with the lexemes muž and žena. Finally, I summarize the results and conclude.

\section{DATA AND RESEARCH QUESTIONS}

My research was provided on the material of the SYN2015 corpus ([12], [13]), a collection of contemporary written Czech texts of the last five-year period (20102014). SYN2015 is divided at the topmost level into three groups: fiction, nonfiction, and newspapers and magazines (NMG).

In my investigation, I used the NMG subcorpus that contains only journalistic texts with total number of $39,744,419$ tokens. The subcorpus is further categorized into eight genres: national press (NTW), regional press (REG), home \& garden, hobby (HOU), lifestyle (LIF), tabloids (SCT), sport (SPO), interesting facts (INT), supplements, Sunday magazines (MIX).

In the analysis of data, I used two different interfaces: the KonText [16] and the paradigmatic query interface [7]. The latter made it possible to compile a classification of examined adjectives which collocate exclusively, almost exclusively or predominantly with the lexemes muž and žena. A detailed discussion concerning the categorisation is presented in paragraph 3 .

The main goal of my study is to systematically describe a profile of premodifying adjectives collocating with the nouns muž or žena ${ }^{1}$ and reveal the gender stereotypical tendencies in journalistic texts. I posed three research questions while investigating examined collocations:

- Are certain adjectives exclusive to one of the examined lexemes?

- Do journalistic texts reflect in collocations with the lexemes muž and žena gender stereotypes?

${ }^{1}$ These two lexemes were chosen as they provide the most generic reference in comparison to more specific terms such as divka 'girl', chlapec 'boy', dáma 'lady', mládenec 'young man'. As my aim is to cover a maximally general view of man and woman in Czech journalistic texts. 
- Is there any connection between certain meanings of semantic categories and the concrete text genres in journalistic texts?

Thanks to the two different interfaces, it was possible to apply a quantitative approach to the data (paradigmatic query interface) as well as a more detailed qualitative approach to identify semantic categories of examined adjectives based on a context (KonText). The next section zooms in on the analysis of adjectival collocations.

\section{ANALYSIS}

The first step in my analysis was to establish the list of "gender-specific" adjectives collocating with the lexemes muž and žena. By "gender-specific" adjectives, I mean adjectives that co-occur exclusively or predominantly only with a noun referring to a female (ex. pretty woman) or male individual (ex. handsome man). I am therefore using the terms feminine, masculine, and neutral adjectives in this work in the above described context but not in the meaning of conventional grammatical gender.

Using the paradigmatic query interface, I looked for collocations by lemma. Adjectival collocates were identified within a span of one word on the left side to capture attributive adjectives which mainly go before a noun [6, pp. 303-304]. The minimum collocate frequency was arbitrarily set to five hits.

In the next step, I divided the identified adjectives into four groups according to a scale of gender-specificity. The boundary of gender-specificity for my research was assumed arbitrarily. I considered an adjective to be masculine or feminine when it collocated in more than $70 \%$ of cases with one of the examined lexemes over the other. In addition, masculine and feminine adjectives were separated into collocates which exclusively, almost exclusively, and predominantly co-occur with the lexemes $m u z ̌$ or žena. The remaining words formed a group of gender-neutral adjectives. The established groups are as follows:

1. exclusively feminine or masculine adjectives - occurring in $100 \%$ of cases only with the lexeme muž or žena;

2. almost exclusively feminine or masculine adjectives - occurring in more than $90 \%$ and less than $100 \%$ of cases with one of the examined lexemes over the other;

3. predominantly feminine and masculine adjectives - occurring in more than $70 \%$ and less than $90 \%$ of cases with one of the examined lexemes over the other;

4. neutral adjectives - occurring $70 \%$ of cases and less with one of the examined lexemes than the other.

The table below presents the adjectival collocates for each group. Only the top 20 results are given for the neutral adjectives. The number in brackets represents the absolute frequency of collocates in the collocation with a noun in NMG. 


\begin{tabular}{|c|c|c|}
\hline Category & Feminine & Masculine \\
\hline $\begin{array}{l}\text { Exclusively } \\
(100 \%)\end{array}$ & $\begin{array}{l}\text { těhotný (184) 'pregnant', } \\
\text { praktický (51) 'practical', } \\
\text { vdaný (29) 'married', } \\
\text { emancipovaný (15) } \\
\text { 'emancipated', kočičí (11) } \\
\text { 'cat-like', nádherný (9) } \\
\text { 'gorgeous', půvabný (9) } \\
\text { 'graceful', lesbický (8) } \\
\text { 'lesbian', lehký (7) 'loose', } \\
\text { rodící (6) ‘giving birth', } \\
\text { vystrašený (6) ‘frightened', } \\
\text { rázný (6) ‘spirited', } \\
\text { bezbranný (6) ‘defenseless', } \\
\text { obřezaný (5) ‘circumcised', } \\
\text { indiánský (5) ‘Indian', } \\
\text { inspirativní (5) ‘inspirational', } \\
\text { sociálnědemokratický (5) } \\
\text { 'social-democratic' }\end{array}$ & $\begin{array}{l}\text { klíčový (40) ‘key’, ženatý (28) ‘married', } \\
\text { ledový (21) ‘ice', maskovaný (19) ‘masked', } \\
\text { železný (16) ‘iron; strong', netopýří (15) ‘bat- } \\
\text { like', pavoučí (13) ‘spider-like', 30letý (12) } \\
\text { '30-year-old', otevřený (11) ‘open', zmrzlý } \\
\text { (9) ‘frozen', trestaný (8) 'punished', čestný } \\
\text { (8) ‘honest', urostlý (8) ‘shapely', smutný } \\
\text { (8) ‘sad', homosexuální (7) ‘homosexual', } \\
\text { holohlavý (6) ‘bald', svalnatý (6) ‘muscular', } \\
\text { hlavní (6) ‘head', zavalený (6) ‘collapsed', } \\
\text { respektovaný (6) 'respected', zlomený (6) } \\
\text { 'broken', sedmasedmdesátiletý (6) ‘77-year- } \\
\text { old', 69letý (5) '69-year-old', prošedivělý (5) } \\
\text { 'graying', galantní (5) 'gallant', bělovlasý (5) } \\
\text { 'white-haired', 56letý (5) ‘56-year-old', 43letý } \\
\text { (5) ‘43-year-old' }\end{array}$ \\
\hline $\begin{array}{c}\text { Almost } \\
\text { exclusively } \\
(>90 \%)\end{array}$ & $\begin{array}{l}\text { kojící (27) breastfeeding', } \\
\text { týraný (25) 'abused', } \\
\text { znásilněný (14) ‘raped', padlý } \\
\text { (12) ‘fallen', ambiciózní (10) } \\
\text { 'ambitious' }\end{array}$ & $\begin{array}{l}\text { svatý (34) ‘holy', třiatřicetiletý (32) ‘33-year- } \\
\text { old', agresivní (28) 'aggressive', ozbrojený } \\
\text { (26) 'armed', rozhněvaný (14) 'angry', } \\
\text { 34letý (14) ‘34-year-old', statný (13) 'burly', } \\
\text { uniformovaný (12) 'uniformed', 29letý (11) } \\
\text { '29-year-old', nenápadný (10) 'discreet', } \\
\text { oběšený (10) 'hanged' }\end{array}$ \\
\hline $\begin{array}{l}\text { Predominantly } \\
\qquad(>70 \%)\end{array}$ & $\begin{array}{l}\text { krásný (173) ‘beautiful', } \\
\text { bývalý (68) ‘ex', sebevědomý } \\
\text { (31) ‘confident', obyčejný } \\
(23) \text { 'ordinary', zavražděný } \\
\text { (14) 'murdered', tehdejší } \\
\text { (13) ‘former', normální } \\
\text { (11) ‘casual', pracující (10) } \\
\text { 'working', rozvedený (10) } \\
\text { 'divorced', tamní (10) ‘local', } \\
\text { aktivní (9) 'active', hezký } \\
\text { (9) 'pretty', kolemjdoucí (9) } \\
\text { 'passersby', zahalený (9) } \\
\text { 'veiled', úžasný (8) 'amazing', } \\
\text { elegantní (7) ‘elegant', } \\
\text { oslovený (7) 'addressed', } \\
\text { samotný (6) 'lonely', evropský } \\
\text { (5) ‘European', konkrétní } \\
\text { (5) ‘major league', ruský (5) } \\
\text { 'Russian', saudský (5) }\end{array}$ & 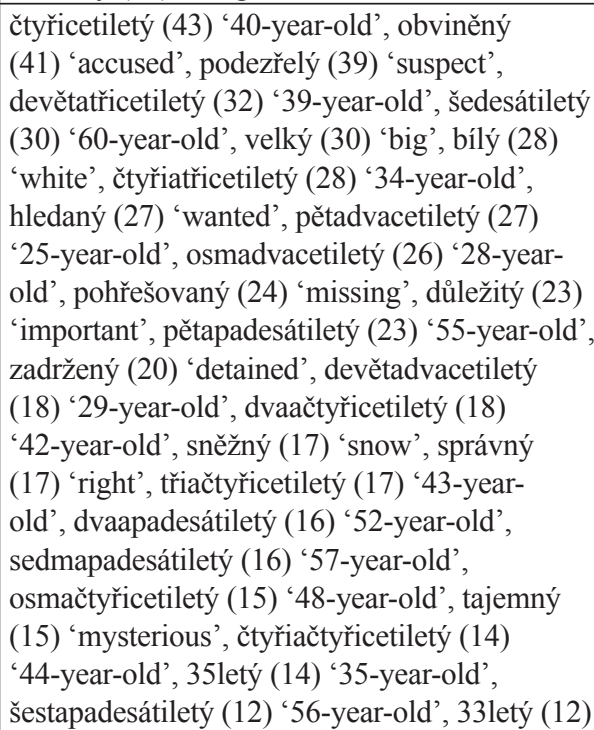 \\
\hline
\end{tabular}




\begin{tabular}{|c|c|c|}
\hline $\begin{array}{l}\text { Predominantly } \\
\qquad(>70 \%)\end{array}$ & $\begin{array}{l}\text { 'Saudi', talentovaný (5) } \\
\text { 'talented' }\end{array}$ & 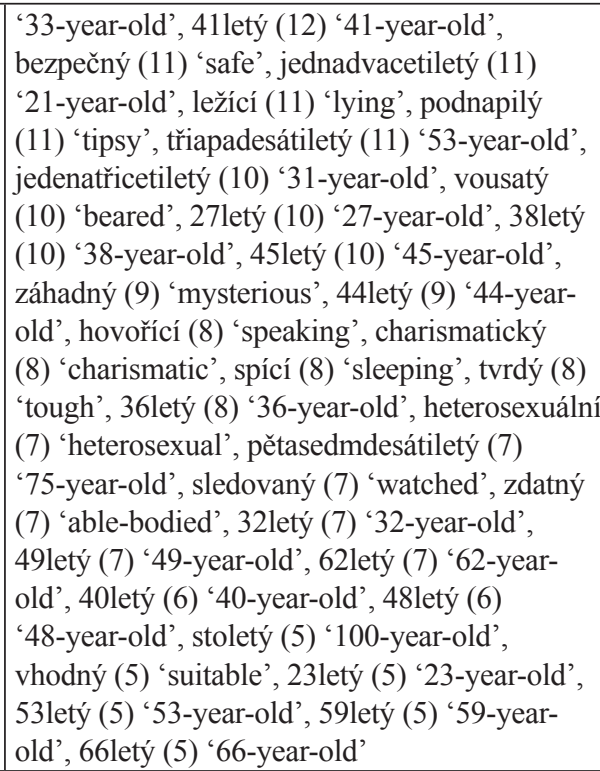 \\
\hline $\begin{array}{c}\text { Neutral } \\
\text { adjectives - } \\
\text { Top } 20\end{array}$ & \multicolumn{2}{|c|}{ 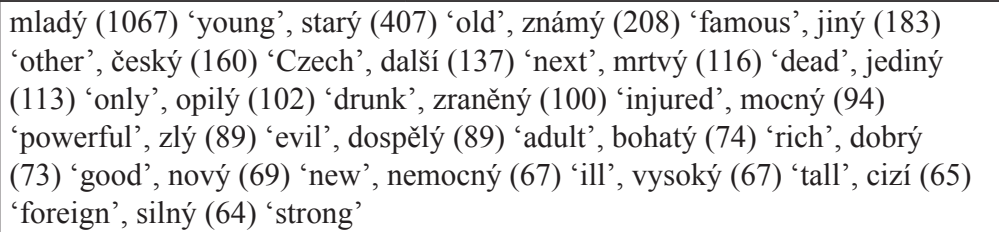 } \\
\hline
\end{tabular}

Tab. 1. Feminine, masculine, and neutral adjectives in Czech journalistic texts

It is noticeable that the group of masculine adjectives is constituted of a larger number of collocates than the group of feminine adjectives (100 adjectives vs. 46 respectively), albeit the occurrence of lexemes žena and muž is comparable, making it respectively 22949 and 22397 hits in NMG. The lexeme žena even has theoretically more possibilities to collocate with adjectives due to a slightly higher occurrence, however, masculine adjectives are twice as frequent. Analyzing masculine adjectives, men are often described by age (30letý '30-year-old', sedmasedmdesátiletý '77-year-old'), strength (železný 'strong'), appearance (urostlý 'shapely', svalnatý 'muscular', statný 'burly'), adjectives evoking negative (trestaný 'punished') and positive (otevřený 'open', čestný 'honest', galantní 'gallant') emotions. On the other hand, almost exclusively and exclusively feminine adjectives are related to motherhood (těhotná 'pregnant', rodicí 'giving birth', kojící 'breastfeeding'), attractiveness (nádherná 'gorgeous', půvabná 'graceful') and adjectives evoking negative emotions or conditions (vystrašená 'frightened', týraná 'abused', znásilněná 'raped', padlá 'fallen'). 
The examined adjectives reveal certain semantic preferences $[20$, p. 65] that make it possible to categorize them into common semantically related groups of words. Moreover, a few adjectival collocations relate to positive and negative prosody, discussed in more details in paragraph 3.1.

\subsection{Sematic categories of gender-specific adjectives}

Based on the apparent semantic characteristics of examined adjectives and inspired by Caldas-Coulthard and Moon's study [5, p. 111], it was possible to introduce semantic categories for analyzed collocates. In comparison with CaldasCoulthard and Moon's categorization, the categorization presented in this study is reduced to the ten following groups: age, strength/supernatural power, appearance/ attractiveness, positive and negative character/social/emotional states ${ }^{2}$, maternity, nationality/ethnicity, action, material status, sexual orientation, and others. Collocates from the Table 1 were categorized into semantic groups to the best of my knowledge by considering their individual context and functions. Table 2 below presents feminine and masculine adjectives by semantic categories.

\begin{tabular}{|c|c|c|}
\hline Category & Feminine & Masculine \\
\hline $\mathrm{Age}^{3}$ & & 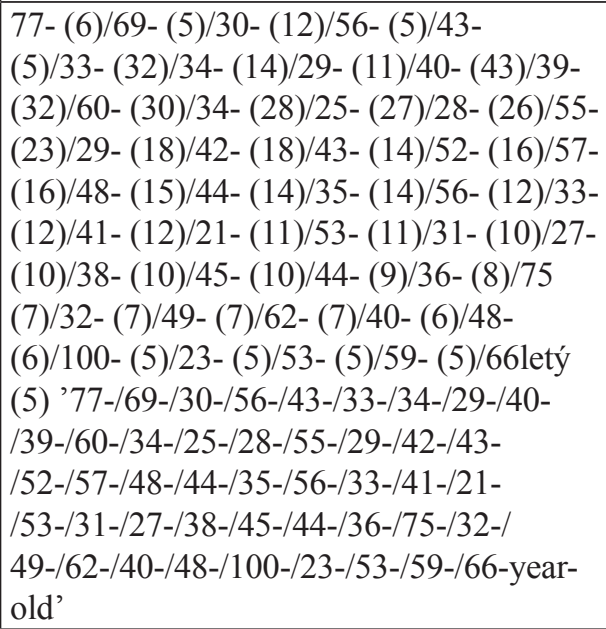 \\
\hline $\begin{array}{l}\text { Strength and } \\
\text { supernatural } \\
\text { power }\end{array}$ & kočičí (11) 'cat' & $\begin{array}{l}\text { železný (16) ‘iron/strong', netopýří (15) } \\
\text { ‘bat', pavoučí (13) ‘spider', tvrdý (8) } \\
\text { 'tough', zdatný (7) 'efficient', }\end{array}$ \\
\hline
\end{tabular}

${ }^{2}$ This category in early study [24] was labelled as character, psychical state, and adjectives evoking positive/negative emotions. However, to avoid possible confusion it was relabelled (for the discussion see [26, pp. 173-174]).

${ }^{3}$ To save space in the table all age specifications were converted to numeric values. 


\begin{tabular}{|c|c|c|c|}
\hline \multicolumn{2}{|c|}{$\begin{array}{l}\text { Appearance } \\
\quad \text { and } \\
\text { attractiveness }\end{array}$} & $\begin{array}{l}\text { nádherný (9) 'gorgeous', } \\
\text { půvabný (9) 'graceful', } \\
\text { krásný (173) 'beautiful', } \\
\text { hezký (9) 'pretty', úžasný } \\
\text { (8) 'amazing', elegantní } \\
\text { (7) 'elegant' }\end{array}$ & $\begin{array}{l}\text { urostlý (8) ‘shapely', holohlavý (6) 'bald', } \\
\text { svalnatý (6) ‘muscular', prošedivělý (5) } \\
\text { 'graying', bělovlasý (5) ‘white-haired', } \\
\text { statný (13) ‘burly', vousatý (10) ‘bearded', } \\
\text { bílý (28) 'white', velký (30) 'big' }\end{array}$ \\
\hline \multirow{2}{*}{ 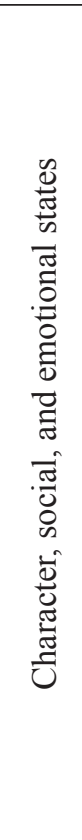 } & 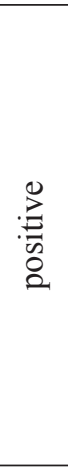 & $\begin{array}{l}\text { praktický (51) } \\
\text { 'practical', inspirativní } \\
\text { (5) 'inspirational', } \\
\text { ambiciózní (10) } \\
\text { 'ambitious', sebevědomý } \\
\text { (31) ‘confident', aktivní } \\
\text { (9) ‘active', rázný (6) } \\
\text { 'spirited', konkrétní (5) } \\
\text { 'concrete', prvoligový } \\
\text { (5) ‘major league', } \\
\text { talentovaný (5) 'talented' } \\
\end{array}$ & $\begin{array}{l}\text { klíčový (40) ‘key’, otevřený (11) ‘open’, } \\
\text { čestný (8) ‘honest', respektovaný (6) } \\
\text { 'respected', hlavní (6) ‘head', galantní (5) } \\
\text { 'gallant', svatý (34) ‘holy', bezpečný (11) } \\
\text { 'safe', důležitý (23) ‘important', správný } \\
\text { (17) 'right', sledovaný (7) ‘watched’, } \\
\text { vhodný (5) ‘suitable’, charismatický (8) } \\
\text { 'charismatic' }\end{array}$ \\
\hline & 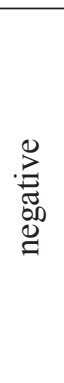 & $\begin{array}{l}\text { lehký (7) 'loose', } \\
\text { vystrašený (6) } \\
\text { 'frightened', bezbranný } \\
\text { (6) ‘defenseless', týraný } \\
(25) \text { 'abused', znásilněný } \\
\text { (14) 'raped', padlý (12) } \\
\text { 'fallen', zavražděný (14) } \\
\text { 'murdered', samotný (6) } \\
\text { 'lonely' }\end{array}$ & $\begin{array}{l}\text { trestaný (8) ‘punished', zlomený (6) } \\
\text { 'broken', ozbrojený (26) ‘armed', oběšený } \\
\text { (10) ‘hanged', obviněný (41) 'accused', } \\
\text { podezřelý (39) ‘suspect', hledaný (27) } \\
\text { 'wanted', pohřešovaný (24) ‘missing', } \\
\text { zadržený (20) ‘detained', podnapilý (11) } \\
\text { 'tipsy', smutný (8) ‘sad', agresivní (28) } \\
\text { 'aggressive', rozhněvaný (14) 'angry', } \\
\text { maskovaný (19) ‘masked' }\end{array}$ \\
\hline \multicolumn{2}{|c|}{ Maternity } & $\begin{array}{l}\text { těhotný (184) 'pregnant', } \\
\text { rodící (6) 'giving birth', } \\
\text { kojící (27) 'breastfeeding', }\end{array}$ & \\
\hline \multicolumn{2}{|c|}{$\begin{array}{l}\text { Nationality } \\
\text { and ethnicity }\end{array}$} & $\begin{array}{l}\text { indiánský (5) ‘Indian’, } \\
\text { ruský (5) ‘Russian’, } \\
\text { saudský (5) ‘Saudi’, } \\
\text { evropský (5) ‘European’ }\end{array}$ & \\
\hline \multicolumn{2}{|c|}{ Action } & $\begin{array}{l}\text { pracující (10) ‘working', } \\
\text { kolemjdoucí (9) ‘passing } \\
\text { by' }\end{array}$ & $\begin{array}{l}\text { ležící (11) ‘lying’, hovořící (8) ‘speaking’, } \\
\text { spící (8) ‘sleeping' }\end{array}$ \\
\hline \multicolumn{2}{|c|}{$\begin{array}{c}\text { Material } \\
\text { status }\end{array}$} & \begin{tabular}{|l|} 
vdaný (29) 'married', \\
rozvedený (10) 'divorced'
\end{tabular} & ženatý (28) 'married' \\
\hline \multicolumn{2}{|c|}{$\begin{array}{c}\text { Sexual } \\
\text { orientation }\end{array}$} & lesbický (8) ‘lesbian’ & $\begin{array}{l}\text { homosexuální (7) 'homosexual', } \\
\text { heterosexuální (7) 'heterosexual' }\end{array}$ \\
\hline
\end{tabular}




\begin{tabular}{|c|c|c|}
\hline Others & $\begin{array}{l}\text { emancipovaný (15) } \\
\text { 'emancipated', obřezaný } \\
\text { (5) ‘circumcised', } \\
\text { sociálnědemokratický } \\
\text { (5) ‘social democratic', } \\
\text { bývalý (68) 'ex', obyčejný } \\
\text { (23) 'ordinary', tehdejší } \\
\text { (13) 'former', normální } \\
\text { (11) ‘casual', tamní (10) } \\
\text { 'local', oslovený (7) } \\
\text { 'addressed', zahalený (9) } \\
\text { 'veiled' }\end{array}$ & $\begin{array}{l}\text { ledový (21) ‘ice’, uniformovaný (12) } \\
\text { ‘uniformed', nenápadný (10) ‘discreet', } \\
\text { sněžný (17) ‘snow', tajemný (15) } \\
\text { 'mysterious', záhadný (9) 'mysterious', } \\
\text { zmrzlý (9) ‘frozen', zavalený (6) } \\
\text { 'collapsed' }\end{array}$ \\
\hline
\end{tabular}

Tab. 2. Feminine and masculine adjectives by semantic categories

While most categories of adjectives modify both muž and žena, fewer categories modify only one of examined lexemes. The categories of maternity and of nationality and ethnicity are represented only by feminine adjectives. It is obvious that in the case of maternity, the lack of masculine adjectives is conditioned largely by biology and in that case we suppose to talk about sex-specific rather than gender-specific adjectives $^{4}$. In the category of nationality and ethnicity, there is a greater interest in discussions of women in sociological discourse that is commensurate with Pearce's findings [18, p. 12].

The age-specification category is only represented by masculine adjectives. The close reading has revealed that the adjectives appear predominantly in crime reports and $m u z ̌$ is more often seen as a perpetrator of crime. These findings are similar to Pearce's conclusion that "men are more strongly associated with crime, violence and the criminal justice system than woman" [18, p. 9]. On the other hand, CaldasCoulthard and Moon observed that "adjectives indicating age are common" [5, p.116]; this might be caused by including gender-neutral adjectives in their analysis as well (ex. young, old etc.).

The other categories are represented by both feminine and masculine adjectives that show different tendencies. In terms of appearance and attractiveness the feminine adjectival collocates emphasize attractiveness, while the masculine adjectival collocates underline appearance. The same conclusion was made by Pearce [18, p. 17] and Caldas-Coulthard and Moon [5, p. 117]. On the contrary, Baker [1, p. 138] observes in the contemporary English language some changes where "men can be now represented in terms of caring about or looking after their appearance."

${ }^{4}$ Buttler [4, pp. 9-11] makes clear binary distinction between the terms gender and sex. Whereas sex is based on biological assumptions and refers to sexual body, gender is a social construct set by society. 
Regarding the strength and supernatural power category, the adjectives mostly refer to superheroes such as kočiči žena 'Catwoman', železný muž 'Ironman', netopýrí muž 'Batman', pavoučí muž 'Spiderman', direct translations from English. These proper names mainly express the image stereotypes and are closely related to other gender-specific proper nouns such as: Barbie and Ken, Adam and Eve etc. Within this category, the correlation between man and strength was also highlighted in the collocation železný muž 'strong man'.

It is also worth noting that the character, social, and emotional states category reveals semantic prosody ([3], [14], [19]). Examined adjectives have positive or negative prosody and represent different gender specifications. Adjectives with positive connotation describe man mainly as a key, open, honest, respected, and head, underlining his importance and high social status. Whereas feminine adjectives such as practical, inspirational, ambitious, confident, and active emphasise the effort of woman who has to constantly prove her abilities. In the term of negative adjectives, further gender stereotypes are revealed. Man is often presented as a perpetrator of crime (trestaný 'punished', podezřely' 'suspect') and woman is a victim of violence (týraný 'abused', znásilněný 'raped') as is consistent with Pearce's [18, p. 19] and Zasina's observations [26, p. 186]. Moreover, there are stressed unfavourable female qualities expressed by euphemisms (lehký 'loose', padly' 'fallen',) and there is expressed male aggressiveness (agresivni 'aggressive', rozhněvaný 'angry').

Furthermore, the sexual orientation category reveals that the adjective heterosexual is masculine because in a journalistic discourse both straight and gay men are compared, and it is essential to stress it. Within the material status category divorced occurs strongly only with woman, pointing to the focus of discussion in the media.

\subsection{Gender-specific collocations within journalistic genres}

In this subsection, I focus on the relation between certain meanings of semantic categories and the concrete text genres in NMG. I zoomed in on the frequency distribution of adjectival collocations with the nouns muž and žena in NMG genres (see Section 2). To compare particular NMG genres, each of which consisted of different number of texts, I used relative frequencies expressed in instances per million (ipm). I took into account all exclusive adjectival collocations from Table 1 and collocations of the two following semantic categories: appearance and attractiveness, and character, social, and emotional states from the Table 2. I chose these two categories because they require a detailed discussion in relation to NMG genres.

First, I examined the exclusive masculine and feminine collocations to investigate general trends in using gender-specific adjectives collocating with $m u \check{z}$ and žena. Figure 1 shows the frequency distribution across NMG genres. 
The NMG genres differ by gender. Results show that feminine collocations are more often in LIF, HOU, and MIX. The LIF and HOU genres are predominantly intended for female readers; therefore articles topics are targeted at women's issues such as pregnancy, marriage, emancipation etc. Hoffmannová [10] also notices that gender stereotypes are presented in women magazines even though they are predominantly edited by women. Masculine collocations, on the other hand, are the most frequent in SPO, MIX, INT. Sport newspapers and magazines seem to be addressed to men and discuss men's issues evidence of which supported by the low occurrence of feminine collocations. The lowest occurrence of masculine collocations in HOU indicates greater focus on female readers.

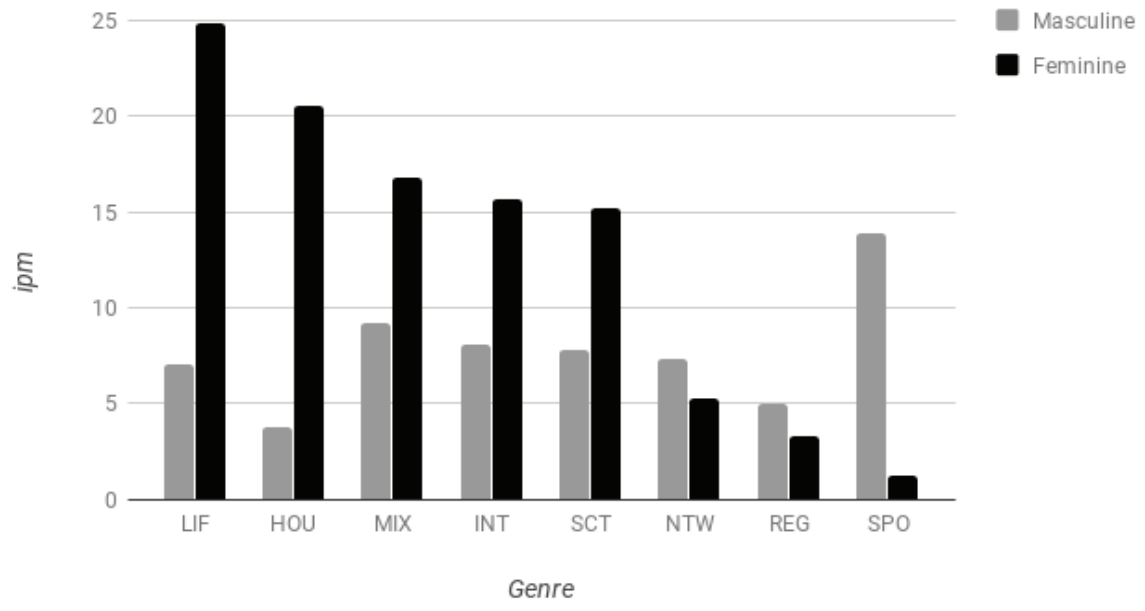

Fig. 1. Distribution of exclusive masculine and feminine adjectives in collocation with the lexemes muž and žena by text genres in NMG

Second, I focus on chosen semantic categories: appearance and attractiveness, and character, social, and emotional states. Figures 2 and 3 show the frequency distribution across NMG genres for each semantic category.

Analysing the data in Figure 2, there is a significantly higher occurrence of feminine collocations within SCT, LIF, and MIX genres. This shows a great interest in female beauty as it is a crucial topic in tabloids and lifestyle magazines. On the other hand, male physical strength and appearance is underlined the most in genres such us INT, SCT, and MIX. Although masculine collocations predominate in INT genre, there is also an interest in women that indicates this genre is dealing with both genders but in a different range. The lowest attention is given to appearance and attractiveness in HOU within both genders and in REG within masculine collocations. 


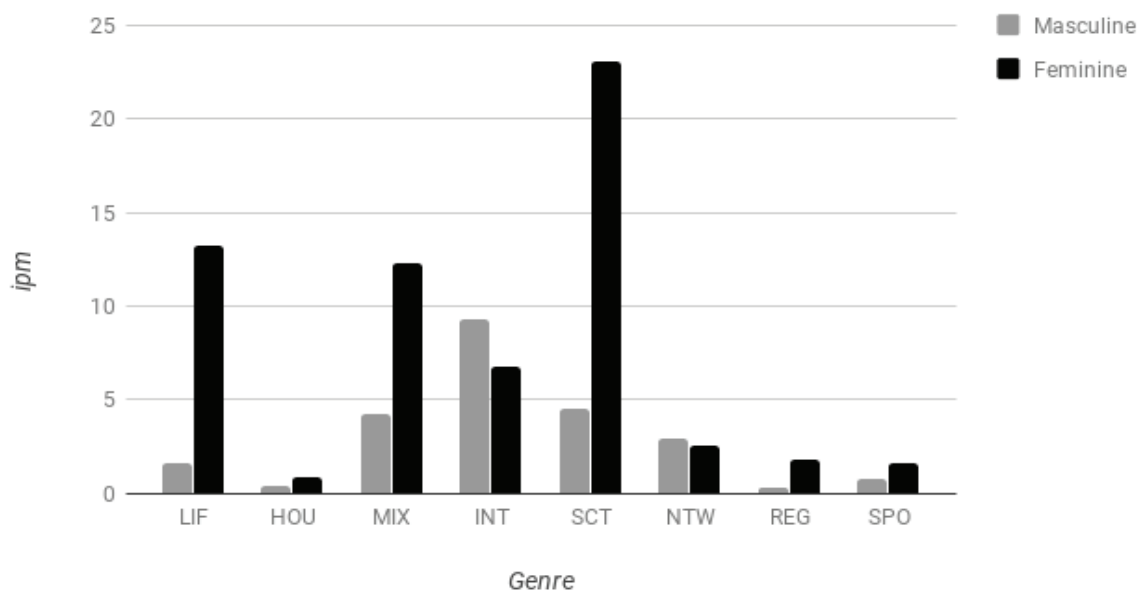

Fig. 2. Distribution of appearance and attractiveness adjectives in collocation with the lexemes $m u z ̌$ and žena by texts genres in NMG

Figure 3 presents the character, social, and emotional states category divided into positive and negative subcategories. The positive masculine collocations are the most represented in INT, and SPO. It is commensurate with my previous statements that these genres are aimed at male readers and describe them mostly in a positive way. In the case of the INT genre, more attention is focused on men than women. On the other hand, the negative masculine collocates are strongly associated with SCT, REG, and NTW. It supports previous findings discussed in subsection 3.1 that negative meaning and men correlate quite often in crime reports. There were no negative masculine collocations in $\mathrm{HOU}$, and the positive ones were rare.

Moreover, analyzing the positive feminine collocations I confirmed that women are strongly seen in a positive light in the HOU and LIF genres. It is notable that these two genres are targeted at a female audience, while the SPO genre is not. Furthermore, the negative feminine collocations are prominent in the SCT and LIF genres. It was expected that tabloids provide for the most part a negative view of women as well as men. Lifestyle magazines seem to build a more positive picture of men and women rather a negative one. There were no negative feminine collocations in HOU genre, which presents only positive qualities.

This section using empirical methods proves that there is a strong relation between gender-specific collocations and journalistic genres. Some genres are more associated with women (LIF, HOU), and others with men (SPO, INT). The analysis of semantic categories confirmed that Czech journalistic texts still project a stereotypical image of men and women. It might be related to readers' expectations of traditional masculine and, feminine roles; however, the further investigation in this area is needed. 


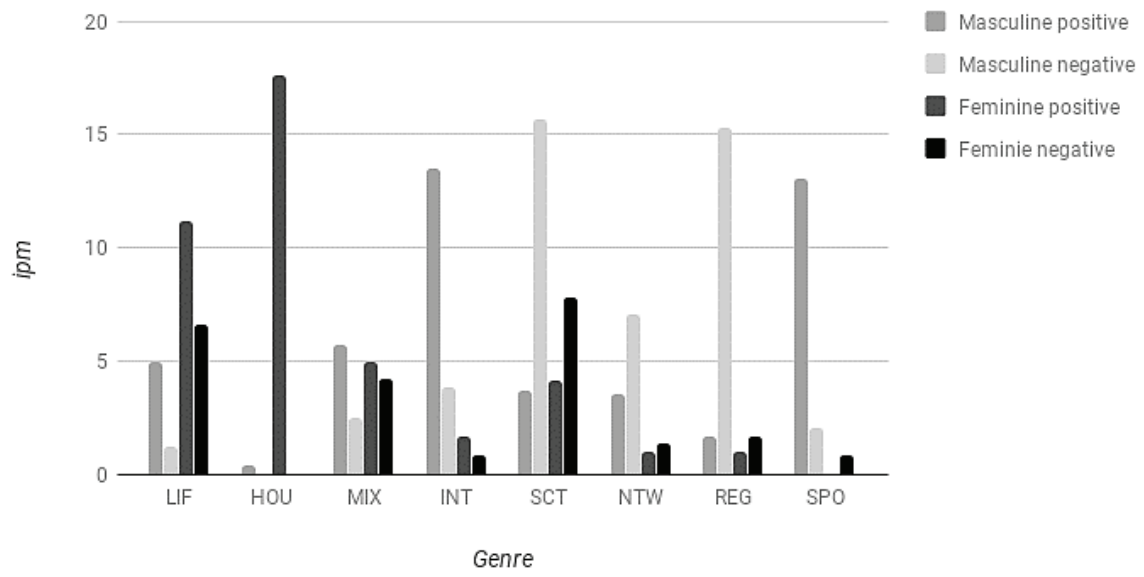

Fig. 3. Distribution of character, social, and emotional states in collocation with the lexemes $m u z ̌$ and žena by texts genres in NMG

\section{CONCLUSION}

The present study focused on gender-specific adjectives in Czech newspapers and magazines. The analysis of adjectival collocations with the lexemes $m u \check{z}$ and žena has confirmed that it is possible to specify adjectives that are exclusively or almost exclusively associated with one of the examined lexemes. Moreover, it has been proven that Czech journalistic texts reflect gender stereotypes in the adjectival collocations. Men pattern strongly with age specification, strength, appearance, and negative situations as a perpetrator of crime. On the other hand, women are portrayed as being mothers, attractive, and victims of crime. Women's nationality or ethnicity is also underlined. Within the positive adjectives of character, social, and emotional states category, both men and women have positives attributes; however, they highlight gender differences. In comparison to the existing literature, this study shares findings with previous English works while bringing new insight in studying gender in Czech; it establishes a comprehensive methodological framework to analyse gender using corpus methods and identifies the gender-specific adjectives with their semantic categories that might be a base for further analyses.

In my work, I also examined the gender-specific collocations within journalistic genres. The analysis has shown that the exclusive masculine and feminine collocations occur in different genres that project stereotypical roles of men and women. The feminine collocations are much more frequent in lifestyle and hobby magazines, whereas the masculine collocations are more frequent in sport magazines and newspapers. Moreover, it was confirmed that there is a connection between certain meanings of semantic categories and concrete journalistic genres. Attractiveness of 
women is for the most part stressed in tabloids and lifestyle magazines, while the appearance of men is underlined in magazines about interesting facts. Further, the investigation of positive and negative character, social, and emotional states has revealed that women are strongly positively portrayed in lifestyle and home \& garden, and hobby magazines, whereas men are predominantly represented in a positive way in magazines about interesting facts, and sport magazines and newspapers. As for negative meaning, both men and women were associated with tabloids. Additionally, men also had negative connotation in regional press.

Contemporary Czech journalistic texts still present a stereotypical image of man and woman. The present study contributes new insights into previous qualitative gender studies ([8], [10], [23]) and complements previous corpus-based gender analyses ([21], [9], [26]). However, it is necessary to carry out further research in this area, which ought to tell us more about the character of man and woman in the Czech language.

\section{References}

[1] Baker, P. (2010). Will Ms ever be as frequent as Mr? A corpus-based comparison of gendered terms across four diachronic corpora of British English. Gender and Language, 4(1), pages 125-149.

[2] Baker, P. (2014). Using corpora to analyze gender. London, Bloomsbury.

[3] Bednarek, M. (2008). Semantic preference and semantic prosody re-examined. Corpus Linguistics and Linguistic Theory, 4(2), pages 119-139.

[4] Butler, J. (1999). Gender trouble: Feminism and the subversion of identity. London, Routledge.

[5] Caldas-Coulthard, C. R., and Moon, R. (2010). 'Curvy, hunky, kinky': Using corpora as tools for critical analysis. Discourse \& Society, 21(2), pages 99-133.

[6] Cvrček, V. et al. (2010). Mluvnice současné češtiny. Praha, Karolinum.

[7] Cvrček, V. (2017). Paradigmatické korpusové dotazy a moderní diachronie. In M. Stluka \& M. Škrabal (eds.), Lifka a czban - Sborník př́spěvků k 70. narozeninám prof. Karla Kučery, pages 117-130. Praha, Czech Republic: Nakladatelství Lidové noviny.

[8] Čmejrková, S. (2003). Communicating gender in Czech. In M. Hellinger, and H. Bußmann (Eds.), Gender across languages: The linguistic representation of women and men, pages 27-58. Amsterdam, John Benjamins Publishing Company.

[9] Elmerot, I. (2017). These women's verbs: a combined corpus and discourse analysis on reporting verbs about women and men in Czech media 1989-2015 (Master's thesis, Stockholm University). Accessible at: https://www.researchgate.net/ publication/ 322539185_These_women's_verbs_-_a_combined corpus_and_discourse_analysis_on_reporting_verbs_about_ women_and men_in_Czech media_1989-2015_Master's thesis

[10] Hoffmannová, J. (2004). Ženy a muži v časopisech pro ženy: Role, perspektivy, výrazové stereotypy. Stylistyka, XIII, pages 27-34.

[11] Huddy, L., and Terkildsen, N. (1993). Gender stereotypes and the perception of male and female candidates. American Journal of Political Science, 37(1), pages 119-147. 
[12] Křen, M., Cvrček, V., Čapka, T., Čermáková, A., Hnátková, M., Chlumská, L., Jelínek, T., Kováŕíková, D., Petkevič, V., Procházka, P., Skoumalová, H., Škrabal, M., Truneček, P., Vondřička, P., and Zasina, A. J. (2015). SYN2015: reprezentativní korpus psané češtiny. Praha, Ústav Českého národního korpusu FF UK. Available at: http: / / www. korpus.cz.

[13] Křen, M., Cvrček, V., Čapka, T., Čermáková, A., Hnátková, M., Chlumská, L., Jelínek, T., Kováŕíková, D., Petkevič, V., Procházka, P., Skoumalová, H., Škrabal, M., Truneček, P., Vondřička, P., and Zasina, A. J. (2016). SYN2015: Representative Corpus of Contemporary Written Czech. In N. Calzolari et al. (Eds.), Proceedings of the Tenth International Conference on Language Resources and Evaluation, pages 2522-2528. Portorož, Slovenia: ELRA.

[14] Louw, B. (1993). Irony in the text or insincerity in the writer? - The diagnostic potential of semantic prosodies. In M. Baker, G. Francis, and E. Tognini-Bonelli (Eds.), Text and Technology: In Honour of John Sinclair, pages 157-176. Amsterdam, John Benjamins.

[15] Macalister, J. (2011). Flower-girl and bugler-boy no more: Changing gender representation in writing for children. Corpora, 6(1), pages 25-44.

[16] Machálek, T., and Křen, M. (2013). Query interface for diverse corpus types. In K. Gajdošová, and A. Žáková (eds.), Natural language processing, corpus linguistics, e-learning, pages 166-173. Lüdenscheid, Germany: RAM Verlag.

[17] Moon, R. (2014). From gorgeous to grumpy: adjectives, age and gender. Gender, and Language, 8(1), pages 99-133.

[18] Pearce, M. (2008). Investigating the collocational behaviour of man and woman in the BNC using sketch engine. Corpora, 3(1), pages 1-29.

[19] Sinclair, J. (2004). Trust the text: Language, corpus and discourse. London, Routledge.

[20] Stubbs, M. (2001). Words and Phrases: Corpus Studies of Lexical Semantics. London, Blackwell.

[21] Šonková, J. (2011). Genderové rozdíly v mluvené češtině. In F. Čermák (Ed.), Korpusová lingvistika. Praha 2011-2 Výzkum a výstavba korpusů, pages 150-165. Praha, ÚČNK Nakladatelství Lidové Noviny.

[22] Taylor, C. (2013). Searching for similarity using corpus-assisted discourse studies. Corpora, $8(1), 81-113$.

[23] Valdrová, J. (2006). Gender a společnost. Ústí nad Labem, Czech Republic: Univerzita J. E. Purkyně.

[24] Zasina, A. J. (2016, November). Adjective collocations with the lexemes muž 'man' and žena 'woman' in Czech journalistic texts. Paper presented at the Young Linguists' Meeting in Poznań 2016. Poznań, Poland.

[25] Zasina, A. J. (2017, July). Premodifying female and male adjectives in journalistic texts. A gender corpus analysis in Czech. Poster presented at Corpus Linguistics 2017. Birmingham, UK.

[26] Zasina, A. J. (2018). Image of Politicians and Gender in Czech Daily Newspapers. In M. Fidler, and V. Cvrček (eds.), Taming the Corpus, From Inflection and Lexis to Interpretation, pages 167-194. Chad, Springer International Publishing. 